\title{
Kewenangan Dewan Keamanan Menghentikan Yurisdiksi ICC : Studi Kasus Resolusi Dewan Keamanan Nomor 1497 Tahun 2003
}

\author{
Sefriani \\ Fakultas Hukum Universitas Islam Indonesia Yogyakarta \\ sefriani@fh.uii.ac.id
}

\begin{abstract}
Though Security Council of the United Nations is a permanent organ within the UN, but this organ is out of the Roma Statute of 1998 coverage. As such, the Security Council in not of the possession of the right to amend the section 16 of the Roma Statute of 1998 which eliminate the jurisdiction of ICC on the UN troops who are the citizen of non state party in the Roma Statute of 1990.
\end{abstract}

Keywords: Keywords: International Criminal Court, Security Council's Resolution no. 1497 of 2003

\section{Pendahuluan}

Keberadaan aturan hierarkhi yang jelas antar sumber hukum juga antar lembaga penegak hukum merupakan sesuatu yang sangat umum sekaligus sangat penting artinya dalam sistem hukum nasional negaranegara yang ada di dunia ini. Sebagai contoh dapat dikemukakan bahwa pada umumnya nilai-nilai fundamental bagi masyarakat diberikan status sebagai konstitusi yang akan diutamakan ketika ada konflik dengan aturanaturan yang dikeluarkan oleh legislation maupun administrasi. Ketentuan administrasi sendiri harus sesuai dengan legislative mandates. Aturan yang tertulis biasanya mengambil precedence dari yang tidak tertulis (unwritten law). Norma hukum akan diutamakan dari yang non hukum (politik dan moral). ${ }^{1}$

Namun tidak demikian halnya dalam hukum internasional dimana senantiasa dikemukakan tidak ada hierarkhi dalam sistem hukum

${ }^{1}$ Dinah Shelton, "Normative Hierarchi in International Law", dalam American Journal of International Law (AJIL) , 100 Am.J.Int'1 L.291, April, 2006, hlm.1 
internasional. ${ }^{2}$ Kecuali mengenai jus cogens atau peremptory norms atau international public order, maka tidak ada hierarkhi antara sumber-sumber hukum yang ada. Dalam Statuta Mahkamah Internasional pun tidak ada aturan mengenai hierarkhi kecuali statement dalam Pasal 38 (1) Statuta Mahkamah Internasional yang menyatakan bahwa Pendapat Hukum serta Putusan Pengadilan merupakan sumber hukum subsider. Namun demikian statement inipun juga tidak berrati bahwa putusan pengadilan maupun pendapat atau karya hukum (writing publicist) tidak boleh bertentangan dengan sumber hukum di atasnya. ${ }^{3}$

Di samping ketiadaan hierarkhi dalam sumber-sumber hukumnya, dalam hukum internasional juga tidak ditemukan hierarkhi antara lembaga formal satu dengan yang lain.Tidak ada lembaga "super body" yang kedudukannya lebih tinggi dari lembaga yang lain. Tidak pula ada lembaga supranasional yang kedudukannya di atas negara-negara dalam semua aspek kehidupan internasional.

Ketiadaan aturan yang jelas mengenai hierakhi dalam sumber hukum maupun lembaga atau institusinya tentu berpotensi menimbulkan masalah bilamana ada konflik antara aturan yang satu dengan aturan yang lain atau konflik kewenangan antara lembaga satu dengan yang lain.

Salah satu contoh yang dapat dikemukakan dalam tulisan ini adalah konflik kewenangan antara Security Council dengan International Criminal Court (ICC) dimana sesungguhnya keduanya merupakan lembaga hukum yang independen satu dengan yang lain. Security Council merupakan salah satu organ utama PBB yang dibentuk oleh Piagam PBB. Adapun keberadaan ICC dibentuk oleh masyarakat internasional melalui Statuta Roma 1998 tentang ICC. ICC tidak diletakkan di bawah struktur PBB. PBB memiliki lembaga pengadilan sendiri yaitu International Court of Justice (ICJ). Seperti halnya Security Council, ICJ juga merupakan salah satu organ utama PBB.

Kehadiran International Criminal Court (ICC) melalui Statuta Roma 1998-nya di tahun 2002 yang lalu seakan menjadi penyegar dahaga kurangnya lembaga penegak hukum bagi masyarakat internasional. Kehadiran lembaga internasional ini mendapat sambutan cukup baik dari masyarakat internasional, terbukti dengan tidak memerlukan waktu

${ }^{2}$ Mochtar Kusumaatmadja, Pengantar Hukum Internasional, Binacipta, Bnadung, 1982, hlm. 14

${ }^{3}$ Dinah Shelton, Op.Cit, hlm.3 
terlalu lama, syarat ratifikasi 60 negara bagi kehadiran ICC segera terpenuhi. ${ }^{4}$ Hal ini juga dapat diartikan bahwa sesungguhnya masyarakat internasional menaruh harapan besar akan lebih baiknya penegakan hukum terhadap pelaku kejahatan internasional dengan kehadiran ICC.

Namun demikian ternyata tidak seperti yang diharapkan, kehadiran ICC pada akhirnya mendapat penolakan dari negara super power Amerika Serikat. Negara yang semula menjadi sponsor ini menjadi khawatir, ICC akan menjadi senjata makan tuan bagi warganya sendiri mengingat seringnya Amerika terlibat dalam konflik-konflik bersenjata baik konflik internasional maupun internal negara lain.Dalam keterlibatannya itu sangat besar kemungkinan anggota pasukan PBB termasuk yang berasal dari Amerika Serikat melakukan kejahatan baik ordinary crime maupun international crime di negara di mana ia ditugaskan. ${ }^{5}$

Berbagai manuver dilakukan Amerika sejak proses perumusan pasalpasal dalam Statuta Roma 1998 sampai setelah ICC secara resmi berdiri untuk menyerang eksistensi ICC. Sebut saja loby-loby yang dilakukan Amerika pada sejumlah negara peratifikasi Statuta Roma untuk menandatangani Perjanjian Bilateral yang isinya kesepakatan kedua belah pihak untuk tidak menyerahkan warga Amerika yang diduga melakukan kejahatan internasional ke depan ICC.

Tidak cukup dengan membuat sekian banyak perjanjian bilateral sebagaimana dikemukakan di atas, Amerika juga menggunakan Dewan Keamanan untuk lebih menegaskan penolakan negaranya terhadap ICC. Sebagai satu-satunya negara super power di Dewan Keamanan yang tentu saja memiliki pengaruh yang besar terhadap anggota Dewan Keamanan lainnya, disertai hak veto yang dimilikinya tidaklah susah bagi Pemerintahan Bush untuk menjadikan Dewan Keamanan sebagai kuda tunggangan politik demi mencapai apa yang diinginkannya. Di sinilah

\footnotetext{
${ }^{4}$ Saat ini sudah lebih dari 100 negara meratifikasi Statuta Roma 1998

${ }^{5}$ Awal tahun 2007 lalu misalnya masyarakat internasional dikejutkan oleh adanya laporan pelecehan seksual juga perkosaan yang dilakukan anggota pasukan penjaga perdamaian PBB terhadap anak-anak dibawah umur di Sudan. Surat kabar Daily Telegrap tertanggal 3 Januari 2007 melaporkan bahwa kejahatan itu sudah berlangsung selama dua tahun, sejak pasukan PBB memasuki Negara itu untuk membantu rekonstruksi Sudan setelah perang saudara selama 23 tahun. Pemerintah Sudan dalam siaran pers-nya menyatakan sudah mengumpulkan bukti-bukti seperti pengakuan sekitar 20 orang yang mengaku dibawa oleh para pekerja PBB dengan kendaraan milik organisasi itu dan dipaksa melakukan hubungan seksual .
} 
mulai terjadi konflik kewenangan antara Dewan Keamanan melalui resolusinya dan ICC melalui Statuta Romanya.

Sebagaimana diketahui proses pemungutan suara di Dewan Keamanan yang beranggotakan 15 anggota tersebut dibedakan menjadi 2, untuk hal-hal non prosedural membutuhkan 9 suara setuju termasuk didalamnya 5 suara bulat anggota tetap Dewan Keamanan. Adapun untuk hal-hal yang bersifat prosedural cukup membutuhkan 9 suara setuju dari 15 suara anggota Dewan Keamanan yang ada. ${ }^{6}$

Pasca perang dingin berdasarkan pengamatan para ahli hukum organisasi internasional memang telah terjadi perubahan yang cukup signifikan dalam proses pemungutan suara di Dewan Keamanan. Bila semasa perang dingin amat sulit bagi lembaga ini untuk mengeluarkan resolusi yang isinya sanksi bagi negara yang diduga melanggar hukum internasional, maka tidak demikian halnya pasca perang dingin. Bila semasa perang dingin banyak sekali penggunaan veto oleh negara pemegang hak veto untuk menggagalkan resolusi yang ditujukan pada negara sekutunya, maka pasca perang dingin justru hampir tidak pernah ada veto.Hal ini dikarenakan tidak ada lagi blok-blokan atau kubu-kubuan dalam tubuh Dewan Keamaanan. Tidak ada lagi 2 kekuatan besar yang senantiasa berseberangan satu sama lain. Satu-satunya kekuatan yang ada tinggallah di tangan Amerika sehingga apapun kemauan negara ini hampir dipastikan tidak pernah tidak berhasil.

Meskipun di satu sisi Dewan Keamanan dapat lebih mudah menjalankan tugasnya karena tidak dihambat oleh veto, tetapi di sisi lain sepak terjang lembaga ini sering melampaui batas kewenangannya. Resolusi yang sedianya digunakan untuk menindak negara pelanggar hukum internasional justru isinya malah melanggar hukum internasional.

Dalam kaitannya dengan ICC, meskipun ICC adalah lembaga yang independen, tidak berada di bawah struktur PBB, namun preambule Statuta Roma 1998 mengakui keberadaan PBB. Preambule menegaskan bahwa pembentukan ICC tidaklah bertentangan dengan Piagam PBB. Terbukti dengan dinyatakannya dalam paragraf ke-7 preambule, bahwa negaranegara pihak Statuta: ...Reaffirming the purposes and Principles of the United Nations, and in particular that all States refrain from the threat or use of force against the territorial integrity or political independence of any State, or in any other manner inconsistent with the purposes of the United Nations.

${ }^{6}$ Pasal 27 Piagam PBB 
Keberadaan pernyataan ini bisa dimaklumi mengingat sampai saat ini PBB adalah organisasi terbesar yang memiliki misi mewujudkan sekaligus memelihara perdamaian dan keamanan internasional yang sangat penting artinya bagi seluruh masyarakat internasional. Di samping itu, Piagam PBB-pun saat ini diterima sebagai konstitusi masyarakat internasional dimana dalam hal ada konflik kewajiban anggota PBB berdasarkan piagam PBB dengan kewajiban yang muncul dalam instrumen hukum yang lain maka kewajiban berdasarkan Piagam PBB lah yang diutamakan. ${ }^{7}$

Salah satu pasal dalam Statuta Roma yang punya keterkaitan erat dengan PBB, khususnya Dewan Keamanan adalah pasal 16 Statuta yang menetapkan sebagai berikut: No investigation or prosecution may be commenced or proceeded with under this Statute for a period of 12 months after Security Council, in a resolution adopted under Chapter VII of the Charter of the United Nations, has requested the Court to that effect; that request may renewed by the council under the same condition.

Berdasarkan pasal tersebut di atas Dewan Keamanan yang memiliki tanggung jawab utama memelihara perdamaian keamanan internasional berhak mengeluarkan resolusinya yang ditujukan pada ICC untuk selama jangka waktu 1 tahun sejak dikeluarkannya resolusi itu ICC tidak dapat melakukan proses hukum terhadap para pelaku kejahatan internasional yang masih ada di bawah perlindungan Dewan Keamanan. Berdasarkan Pasal itu pula dapat ditafsirkan bahwa kewenangan tersebut hanya digunakan dalam kaitannya dengan pelaksanaan BAB VII Piagam PBB tentang Action with Respect to threats to the Peace, Breaches of the Peace, and Acts of Agression.

Berkaitan dengan kewenangan yang diberikan Pasal 16 Statuta Roma di atas pada tanggal 12 Juli 2002, Dewan Keamanan mengadopsi Resolusi Nomor 1422 yang meminta ICC tidak melakukan investigasi dan proses penuntutan lain terhadap UN Peacekeeper di Bosnia Herzegovina. ${ }^{8}$

Resolusi ini usulan Amerika Serikat yang menginginkan imunitas bagi personil militernya di Bosnia Herzegovina. Amerika mengancam akan menggunakan vetonya untuk tidak memperpanjang misi perdamaian PBB di Bosnia yang akan berakhir 15 Juli 2002, bila draft resolusinya ditolak.

\footnotetext{
${ }^{7}$ Pasal 103 Piagam PBB

${ }^{8}$ Neha Jain, " A Separate Law for Peacekeepers : The Clash Between The Security Council and The International Criminal Court", dalam European Journal of International Law, April, 2005, hlm 2
} 
Demikianlah usulan Amerika diadopsi melalui Resolusi nomor 1422. Pada prinsipnya Resolusi ini menolak yurisdiksi ICC terhadap personil Pasukan Perdamaian PBB yang berasal dari negara yang tidak meratifikasi Statuta Roma 1998( Non-State party). ${ }^{9}$

Meski mendapat penolakan dari beberapa negara, skenario yang sama terjadi pula pada Resolusi 1487 yang merupakan perpanjangan Resolusi 1422 yang berakhir 30 Juni 2003. Paragraf 8 point 1 kedua Resolusi menetapkan sebagai berikut:

Request, consistent with the provisions of Article 16 of the Rome Statute, that ICC, if a case arises involving current or former officials or personnel from a contributing State not a Party to the Rome Statute over actor omissions relating to a United Nations established or authorized operation, shall for a 12-month period starting 1 July 2003 not commence or proceed with investigation or persecution of any such case, unless the Security Council decides otherwise.

Tidak puas dengan dua resolusi tersebut di atas, menggunakan pengaruh yang dimilikinya, Pada tanggal 1 Agustus 2003 Amerika Serikat kembali berhasil membuat anggota Dewan Keamanan yang lain bertekuk lutut dengan berhasil diadopsinya Resolusi nomor 1497. Resolusi ini berkaitan dengan misi pasukan perdamaian PBB di Liberia. Paragraf 7 Resolusi 1497 menetapkan sebagai berikut:

Decides that current or former officials or personnel from a contributing State, which is not a party to the Rome Statute of the International Criminal Court, shall be subject to the exclusive jurisdiction of that contributing State for all alleged acts or omissions arising out of or related to the Multinational Force or United Nations stabilizations force in Liberia, unless such exclusive jurisdiction has been expressly waived by that contributing State.

Meskipun kandungannya mengandung makna sama dengan dua resolusi sebelumnya yaitu mengecualikan anggota pasukan PBB yang berasal dari Non-State Party dari yurisdiksi ICC, namun Resolusi 1497 tidak menggunakan dasar Pasal 16 Statuta Roma 1998. Resolusi ini juga tidak memuat batas waktu penerapan seperti dua resolusi sebelumnya yang dengan tegas menyatakan waktu 12 bulan masa berlaku. Dengan tidak adanya pembatasan waktu maka dapat ditafsirkan bahwa anggota pasukan PBB yang berasal dari non-StateParty yang ditugaskan di Liberia, 
termasuk didalamnya dari Amerika Serikat, akan memiliki imunitas atau kekebalan dari proses hukum di depan ICC kecuali negara asalnya menanggalkan kekebalan warganya tersebut.

Resolusi 1497 menunjukkan arogansi Dewan Keamanan khususnya Amerika Serikat yang tidak mau tunduk pada yurisdiksi ICC. Keberadaan Resolusi tentu saja menimbulkan ketidaknyamanan bagi anggota Pasukan PBB yang berasal dari negara pihak dalam Statuta Roma 1998 mengingat terhadap mereka berlaku yurisdiksi ICC. Tentu saja hal ini merupakan diskriminasi. Perlakuan yang diskriminatif ini dikhawatirkan akan kontra produktif dengan semangat melibatkan negara seluas-luasnya sebagai negara pihak dalam Statuta Roma 1998.

Di sisi lain, Resolusi 1497 juga dapat dipandang tidak sesuai dengan pasal 16 Statuta Roma 1998 yang mengamanatkan batas waktu 12 bulan sejak Resolusi dikeluarkan bagi pengecualian dari yurisdiksi ICC. Resolusi 1497 juga menimbulkan pertanyaan seiring dengan persyaratan yang ditetapkan oleh Pasal 16 bahwa diijinkannya penggunaan Pasal 16 oleh Dewan Keamanan hanya dalam rangka penerapan Bab VII Piagam tentang Action with Respect to threats to the Peace, Breaches of the Peace, and Acts of Agression. Pertanyaan lebih lanjut adalah apakah Resolusi 1497 yang memberikan imunitas bagi anggota UN Peacekeeper di Liberia berkaitan dengan masalah ancaman terhadap perdamaian, pelanggaran terhadap perdamaian atau tindakan agresi?

Sekali lagi, masalah tidak adanya hierarkhi dalam hukum internasional, baik hierarkhi dalam instrumen hukum maupun hierarkhi kelembagaan, sangat berpotensi menimbulkan konflik di lapangan ${ }^{10}$ seperti halnya dalam kasus di atas, apakah Dewan Keamanan berwenang untuk menghentikan yurisdiksi ICC? Apa akibat hukumnya bila Resolusi Dewan Keamanan ternyata bertentangan dengan Piagam PBB? Berangkat dari uraian di atas tulisan berikut akan menganalisis lebih dalam Kewenangan Dewan Keamanan menghentikan yurisdiksi ICC: Studi kasus Resolusi Dewan keamanan Nomor 1497 Tahun 2003.

\section{Yurisdiksi ICC terhadap Warga dari Non State Party}

ICC adalah subjek hukum internasional yang memiliki international personality. Dengan demikian ICC dapat melakukan berbagai international

${ }^{10}$ Shelton, Dinah, Op.Cit., , hlm.3 
legal capacity dalam rangka pelaksanaan fungsinya. ${ }^{11}$ ICC dapat melaksanakan fungsi dan kewenangannya di wilayah negara anggota juga dengan perjanjian khusus di wilayah negara lain. ${ }^{12}$

Yurisdiksi ICC terbatas pada kejahatan yang paling serius bagi masyarakat internasional secara keseluruhan yakni genocide, crimes against humanity, war crimes serta crime of aggression. ${ }^{13}$ Yurisdiksi ICC tidak berlaku surut, hanya dapat diberlakukan terhadap the most serious crimes tersebut setelah berlakunya Statuta Roma 1998 dan setelah suatu negara menjadi pihak dalam Statuta, kecuali negara ini membuat deklarasi khusus. ${ }^{14}$

Pasal 12 Statuta Roma 1998 menetapkan bahwa ICC dapat melaksanakan yurisdiksinya bila satu atau lebih negara berikut adalah peserta statuta atau telah menerima yurisdiski ICC berdasar ayat 3: (a) negara yang berkuasa atas wilayah dimana perbuatan dipersoalkan itu terjadi atau kalau kejahatan itu dilakukan di atas kapal atau pesawat terbang , negara dimana kapal atau pesawat terbang itu terdaftar; (b) negara dimana orang yang dituduh melakukan kejahatan adalah warganegara.

Dari ketentuan Pasal 12 paragraf a dapat disimpulkan bahwa bila negara tempat perbuatan atau kejahatan dilakukan merupakan negara peratifikasi Statuta Roma maka ICC dapat melaksanakan yurisdiksinya. Tentu saja hal itu tetap terikat pada ketentuan bahwa ICC merupakan pengadilan pelengkap. Bila pengadilan nasional dari negara tempat dilakukannya kejahatan tidak mampu atau tidak mau melaksanakan yurisdiksinya maka ICC dapat melaksanakan yurisdiksinya. Kewenangan ICC untuk untuk menerapkan yurisdiksinya ketika kejahatan terjadi di wilayah negara peratifikasi Statuta Roma ini mengabaikan kewarganegaraan pelaku. Dengan demikian ICC akan tetap memiliki yurisdiksi sekalipun pelaku berasal dari negara yang tidak meratifikasi Statuta Roma (non state party)

Dalam pelaksanaan yurisdiksinya, selain tidak dapat melakukan penyelidikan dan penuntutan akibat kewenangan yang diberikan Statuta pada Dewan keamanan dalam Pasal $16^{15}$ maka, ICC juga tidak dapat melaksanakan yurisdiksinya bilamana: ${ }^{16}$ (a) kasusnya sedang diselidiki

\footnotetext{
${ }^{11}$ Pasal 4(1) Statuta Roma 1998

${ }^{12}$ Pasal 4(2) Statuta Roma 1998

${ }^{13}$ Pasal 5(1) Statuta Roma 1998.

${ }^{14}$ Pasal 11 Statuta Roma 1998

${ }^{15}$ lihat halaman 5 artikel ini

${ }^{16}$ Pasal 17 (1)
} 
atau dituntut oleh negara yang memiliki yurisdiksi terhadap kasus tersebut kecuali bila negara itu tidak bersedia atau benar-benar tidak dapat melakukan penyelidikan atau penuntutan; (b) kasusnya telah diselidiki oleh suatu negara yang memiliki yurisdiksi dan negara itu memutuskan untuk tidak menuntut orang yang bersangkutan kecuali kalau putusan tersebut muncul dari ketidaksediaan atau ketidakmampuan negara itu untuk benar-benar melakukan penuntutan; (c) orang yang bersangkutan telah diadili atas perbuatan yang merupakan pokok pengaduan; ${ }^{17}$ (d) kasusnya tidak cukup gawat untuk membenarkan tindakan lebih lanjut oleh ICC.

Masih erat kaitannya dengan pembatasan yurisdiksi ICC, bila Pasal 17, menyangkut imunitas pelaku the most serious crime maka Pasal 98 Statuta Roma 1998 menetapkan sebagai berikut: (a) The court may not proceed with a request for surrender assistance which would require the requested State to act inconsistently with its obligations under international law with respect to the State or diplomatic immunity of a person or property of a third State, unless the court can first obtain the cooperation of the third State for the waiver of the immunity; (b) The court may not proceed with a request for surrender which would require the requested State to act inconsistently with its obligations under international agreements pursuant to which the consent of a sending State is required to surrender a person of that State to the Court, unless the Court can first obtain the cooperation of the sending State for the giving of consent for the surrender.

Pasal tersebut menetapkan bahwa ICC tidak dapat melanjutkan suatu permintaan penyerahan atau bantuan yang kiranya mengharuskan negara yang mendapat permintaan akan bertindak tidak konsisten dengan kewajiban-kewajibannya di bawah hukum internasional berkenaan dengan negara atau kekebalan diplomatik dari orang atau kekayaan dari suatu negara ketiga, kecuali kalau ICC dapat memperoleh kerjasama dari negara ketiga itu sebelumnya, untuk penanggalan kekebalan. ICC juga tidak dapat melanjutkan suatu permintaan untuk penyerahan yang akan mengharuskan negara yang menerima permintaan bertindak tidak konsisten dengan kewajibannya berdasarkan perjanjian internasional yang sesuai dengan itu, persetujuan dari negara pengirim dibutuhkan

${ }^{17} \mathrm{Hal}$ ini merupakan penerapan prinsip neb is in idem yang dikenal dalam hukum pidana.namun demikian prinsip ini dapat diabaikan bila memenuhi syarat yang ada dalam pasal 20(3) Statuta Roma 1998 
untuk penyerahan warganegaranya ke ICC, kecuali bila ICC telah memperoleh kerjasama/persetujuan dari negara pengirim untuk penyerahan tersebut. Dengan demikian dapat ditafsirkan, menyangkut negara ketiga atau negara non pihak dalam Statuta, ICC tidak memiliki yurisdiksi otomatis yaitu ketika negara ketiga itu memiliki perjanjian dengan negara peratifikasi ICC seperti perjanjian ekstradisi misalnya, atau juga ketika pelaku adalah orang yang memiliki kekebalan menurut hukum internasional, kecuali negara ketiga tersebut dengan sukarela menyerahkan warganya atau mungkin menanggalkan kekebalan orang yang dimaksud. ${ }^{18}$

Namun demikian masih dalam kaitannya dengan imunitas pelaku, Pasal 27 Statuta menetapkan bahwa statuta berlaku sama terhadap semua orang tanpa ada suatu perbedaan atas dasar jabatan resmi. Jabatan resmi seperti Kepala Negara, Kepala Pemerintahan, anggota suatu pemerintahan atau parlemen, wakil terpilih atau pejabat pemerintah dalam hal apapun tidak mengecualikan seseorang dari tanggung jawab berdasarkan Statuta. Demikian pula mengenai dirinya sendiri tidak merupakan suatu alasan untuk mengurangi hukuman. Kekebalan atau peraturan prosedural khusus yang mungkin terkait dengan jabatan resmi seseorang baik di bawah hukum nasional maupun internasional tidak menghalangi ICC untuk melakukan yurisdiksinya atas orang tersebut. Dari ketentuan tersebut dapat ditafsirkan bahwa ICC tidak memberikan imunitas kepada seseorang pelaku the most serious crime terkait dengan jabatan yang dimilikinya, semua orang berkedudukan sama di depan ICC.

\section{Resolusi 1497 bertentangan dengan Hukum Internasional}

\section{Resolusi 1497 bertentangan dengan Piagam PBB}

Pada 1 Agustus 2003 dalam rangka pelaksanaan BAB VII Piagam PBB, Dewan Keamanan berhasil mengadopsi Resolusi Nomor 1497. Resolusi ini dianggap penting untuk dikeluarkan mengingat konflik di Liberia sedemikian rupa telah menimbulkan masalah kemanusiaan dan destabilisasi wilayah yang serius juga mengancam perdamaian keamanan internasional Resolusi juga dipandang penting untuk menciptakan situasi lingkungan kondusif bagi penghormatan HAM termasuk rehabilitasi dan

${ }^{18}$ Audrey 1. Benison, "International Criminal Tribunal : Is there a Substantive Limitation on theTReaty Power", dalam Stanford Journal of International Law, Winter 2001, hlm. 546 
perlindungan kemanusiaan penduduk sipil dan mendukung misi pekerja kemanusiaan. Di samping itu, resolusi juga dipandang penting untuk mendukung pelaksanaan perjanjian gencatan senjata 17 Juni 2003 untuk terciptanya perdamaian. ${ }^{19}$

Untuk berhasilnya memulihkan situasi di Liberia melalui Resolusi 1497, Dewan Keamanan merasa perlu untuk membentuk Multinational Force. Mandat yang diberikan pada Multinational Force tersebut sangat luas, termasuk di dalamnya perlucutan senjata, aktifitas demobilisasi dan reintegrasi, pemeliharaan keamanan, menjamin lingkungan untuk pengiriman bantuan kemanusiaan, juga.menyediakan pasukan perdamaian dalam jangka waktu yang lebih lama untuk menstabilkan kondisi di daeraah konflik. Dengan kata lain Dewan Keamanan memberi kewenangan negara-negara untuk membentuk suatu peace enforcement mission. Negara-negara yang bergabung dengan pasukan di bawah bendera PBB saat itu adalah Pasukan Nigeria, Ghana, Mali, Senegal dan Amerika Serikat. Misi ini merupakan tahap awal yang akan dilanjutkan dengan misi kedua berupa peace process.

Proses adopsi Resolusi 1497 ditentang 3 negara yaitu Mexico, Jerman dan Perancis. Ketiga negara ini menyatakan bahwa mereka tidak mampu memberikan suara mereka untuk resolusi tersebut karena ketentuanketentuan dalam resolusi tidak berhubungan dengan situasi di Liberia.dan bertentangan dengan prinsip hukum nasional maupun internasional.

Sesuai dengan tugas utamanya, Dewan Keamanan PBB dapat mengambil tindakan-tindakan dalam kerangka BAB VII Piagam untuk merespons terjadinya ancaman terhadap perdamaian keamanan internasional, pelanggaran terhadap perdamaian keamanan internasional maupun juga terhadap terjadinya tindakan agresi, manakala Dewan Keamanan berdasarkan Pasal 39 Piagam telah menetapkan terpenuhinya kondisi-kondisi tersebut. Praktek Dewan Kemanan menunjukkan bahwa Pasal 39 ditafsirkan secara sangat luas dan tidak konsisten. Sebagai contoh dalam kasus Lockerbie misalnya 4 tahun setelah insiden peledakan Kapal Pan Am milik Inggris tidak pernah terjadi insiden apapun, tetapi oleh Dewan Keaman kasus Lockerbie ini digolongkan mengancam perdamaian dan keamanan internaisonal. Demikian halnya Irak yang tidak pernah terbukti menyimpan atau mengembangkan senjata pemusnah masal

\footnotetext{
${ }^{19}$ Salvatore Zappala," Are Some Peacekeepers Better Than Others? UN Security Council Resolution 1497 (2003) and the ICC", dalam Journal of International Criminal Justice , 671, December, 2003, hlm.1
} 
dikategorikan melanggar perdamaian keamanan internasional. ${ }^{20}$ Kegagalan Pemerintah Libya menunjukkan penolakannya terhadap terorisme juga dikategorikan sebagai ancaman terhadap perdamaian keamanan internasional. ${ }^{21}$ Sebaliknya tindakan brutal Israel terhadap warga Palestina termasuk menggusur pemukiman warga untuk didirikan tembok pembatas tidak pernah dikategorikan sebagai tindakan mengancam apalagi melanggar perdamaian keamanan internasional. ${ }^{22}$ Penafsiran yang sangat luas dan tidak konsisten dapat dipahami mengingat putusan Dewan Keamanan bersifat politis.

Apabila paragraph 1 Resolusi memberikan dasar perimbangan adanya ancaman perdamaian keamanan internasional di Liberia sehingga perlu dikeluarkan resolusi 1497 juga perlunya pembentukan pasukan perdamaian PBB maka paragraph 7 resolusi ini menetapkan sebagai berikut:

Decides that current or former officials or personnel from a contributing State, which is not a party to the Rome Statute of the International Criminal Court, shall be subject to the exclusive jurisdiction of that contributing State for all alleged acts or omissions arising out of or related to the Multinational Force or United Nations stabilizations force in Liberia, unless such exclusive jurisdiction has been expressly waived by that contributing State

Mencermati isi paragraph tersebut dapat dikemukakan bahwa sesungguhnya tidak ada kaitannya antara ancaman perdamaian keamanan serta situasi di Liberia di satu sisi dengan perlunya memberi yurisdiksi eksklusif pada Negara Non anggota Statuta Roma di sisi lain, sehingga memerlukan dikeluarkannya suatu Resolusi untuk menghambat yurisdiksi ICC.

Keduanya merupakan hal yang berbeda sama sekali. Nampak jelas dalam paragraph 1 Resolusi bahwa pertimbangan telah terjadi ancaman perdamaian keamanan internasional adalah karena situasi di Liberia yang sarat dengan konflik sehingga menimbulkan masalah kemanusiaan dan destabilisasi wilayah yang serius sama sekali tidak menyinggung masalah imunitas anggota pasukan PBB. Jelas sekali ketentuan mengecualikan anggota pasukan PBB yang berasal dari non state party sangat tidak memiliki landasan hukum, yang ada hanyalah melindungi kepentingan

\footnotetext{
${ }^{20}$ Sabahi, Babback, Op.Cit., hlm 3

${ }^{21}$ Neha Jain, Op.Cit., hlm.4

${ }^{22}$ Sabahi, Babback, Loc.Cit
} 
Negara non state party itu sendiri. Dalam siaran persnya Sekretaris Jendral PBB mengemukakan bahwa ...the attempts to protect international UN Peacekeepers from prosecution of the kind that is intended in the resolution is really not necessary ... and quite frankly, my sentiments arewith those who abstained from the resolution... ${ }^{23}$ Fakta yang muncul di lapangan sesungguhnya adalah adanya ancaman dari Amerika Serikat untuk tidak memperpanjang maupun membentuk misi-misi PBB untuk perdamaian jika ICC dibiarkan melaksanakan yurisdiksinya. Justru ancaman inilah yang menurut para pakar layak dikategorikan sebagai ancaman terhadap perdamaian keamanan internasional. Di samping tidak ada pertautan sama sekali antara masalah ancaman perdamaian keamanan di Liberia dengan perlunya memberikan imunitas pada anggota Negara pengirim yang non state party, sesungguhnya Liberia adalah juga non state party pada Statuta Roma. Dengan demikian sungguh tidak beralasan untuk mengkhawatirkan masuknya yurisdiksi ICC pada anggota pasukan yang dikirim ke Liberia yang berasal dari non state party. Tanpa paragraf 7 itupun segala tindakan pelanggaran hukum yang dilakukan personil PBB di Liberia tidak dapat masuk ke yurisdiksi ICC. Dengan demikian sangat jelas bahwa Resolusi 1497 tidak hanya bermaksud membatasi yurisdiksi ICC tetapi memberikan kewajiban pada semua negara untuk mengecualikan anggota pasukan PBB dari non state party dari segala jenis pelanggaran atau kejahatan secara umum atau menyeluruh, tidak dibatasi oleh ruang maupun waktu. ${ }^{24}$

Di samping syarat adanya kondisi ancaman atau pelanggaran terhadap perdamaian keamanan internasional serta pelanggaran agresi, suatu Resolusi Dewan Keamanan juga dibatasi prinsip-prinsip tertentu PBB, dalam hal ini adalah Dewan Keamanan sesuai dengan Pasal 2(7) Piagam pada dasarnya tidak diperbolehkan untuk mengadakan campur tangan terhadap urusan dalam negeri suatu negara, kecuali tindakan campur tangan tersebut dalam rangka pengenaan sanksi baik ekonomi maupun militer kepada negara yang tidak mentaati keputusan Dewan Keamanan atas pelanggaran yang dapat mengancam termasuk tindakan agresi (BAB VII Piagam). ${ }^{25}$

\footnotetext{
${ }^{23}$ Lihat press conference by the Secretary General following the Security Council meeting on Liberia , 1 August 2003 reported at http:/ / www.un.org/appsssss/sg/ ofthecuff,asp/nid+458\#

${ }^{24}$ Salvatore Zappala, Op.Cit., hlm.2

${ }^{25} \mathrm{Ibid} .$, hlm. 160
} 
Dewan Kemaanan tidak dapat bertindak di luar ketentuan yang telah ditetapkan dalam Pasal 24 (2) dan Pasal 1(1) Piagam. Menurut Pasal 24 (1) semua tindakan yang dilakukan Dewan Keamanan harus tetap didasarkan atas prinsip-prinsip dan tujuan PBB yaitu tetap menghormati persamaan kedaulatan, hak negara untuk mempertahankan kemerdekaan politik dan keutuhan wilayahnya. Di samping itu, tindakan Dewan Keamanan juga harus didasarkan prinsip-prinsip keadilan dan hukum internasional tanpa merugikan kepentingan suatu negara. ${ }^{26}$

Ketentuan yang tercantum dalam paragraph 7 Resolusi 1497 jelasjelas memberikan perlakuan berbeda antara anggota pasukan PBB yang berasal dari negara pihak Statuta Roma dengan yang berasal dari negara non anggota Statuta Roma. Dengan memberikan yurisdiksi eksklusif pada negara pengirim maka pelanggaran apapun yang dilakukan oleh anggota pasukan PBB yang berasal dari negara non pihak Statuta Roma, hanya negara pengirim yang memiliki yurisdiksi. Adapun apabila yang melakukan pelanggaran yang sama adalah anggota pasukan yang berasal dari negara pihak Statuta Roma maka negara territorial, negara asal korban juga ICC memiliki yudicial jurisdiction terhadapnya. Jelaslah diskriminasi ini bertentangan dengan prinsip-prinsip keadilan dan merugikan negara lain.

Dalam salah satu argumentasinya untuk mempertahankan Resolusi 1497 Amerika mengemukakan bahwa berdasarkan Pasal 103 Resolusi Dewan Keamanan memiliki kedudukan yang lebih tinggi dari perjanjian internasional yang lain sehingga apabila ada ketidakselarasan maka Resolusilah yang harus diutamakan. Secara rinci Pasal 103 menetapkan sebagai berikut: In the event of a conflict between the obligationsof the members of the United Nations under the present Charter and their obligations under any other international agreement, their obligation under the present Charter shall prevail.

Pasal 103 di atas dapat dipahami mengingat kedudukan Piagam PBB sampai saat ini dipandang sebagai konstitusi masyarakat bangsa-bangsa. Tidak bisa disangkal bahwa piagam PBB mengandung nilai-nilai hukum yang derajatnya lebih tinggi dibandingkan dengan perjanjian-perjanjian internasional lainnya, baik yang ada dan sudah berlaku jauh sebelum maupun yang ada sesudah mulai berlakunya Piagam. Meskipun hukum internasional sebagai hukum koordinatif tidak mengenal tingkatan-

\section{${ }^{26} \mathrm{Ibid}$}


tingkatan atau hierarkhi di dalam sistem hukum atau peraturan perundang-undangan nasional, namun dari segi common sense, bahwa adanya tingkatan atau hierakhi seperti yang dinyatakan oleh pasal 103 Piagam adalah sesuatu yang sulit untuk disangkal. ${ }^{27}$

Memang benar apa yang dikemukakan Amerika bahwa Resolusi 1497 memberikan kewajiban-kewajiban pada anggota PBB dalam kerangka PBB mengingat Dewan Keamanan adalah organ utama PBB dan bertindak atas nama PBB. Hal ini juga dikuatkan oleh pasal 25 Piagam yang menyatakan bahwa ...the member of the United Nations agree to accept and carry out the decision of the Security Council in accordance with the Present Charter. Namun demikian harus diingat bahwa Pasal 25 pun mensyaratkan kesesuaian antara Resolusi dengan Piagam. Demikian juga halnya dengan Pasal 24 seperti telah dipaparkan sebelumnya yang mensyaratkan bahwa semua tindakan yang dilakukan Dewan Keamanan harus tetap didasarkan atas prinsip-prinsip dan tujuan PBB yaitu tetap menghormati persamaan kedaulatan, hak negara untuk mempertahankan kemerdekaan politik dan keutuhan wilayahnya. Di samping itu, tindakan Dewan Keamanan juga harus didasarkan pada prinsip-prinsip keadilan dan hukum internasional tanpa merugikan kepentingan suatu negara. ${ }^{28}$

Manakala syarat-syarat itu tidak terpenuhi mengingat Resolusi membatasi kedaulatan banyak negara, merugikan kepentingan banyak negara, melanggar prinsip persamaan kedudukan antarnegara, juga tidak ada kaitannya antara pemberian imunitas dengan masalah perdamaian keamanan maka dapat disimpulkan bahwa Dewan Keamanan telah bertindak ultra vires, konsekuensinya ketentuan yang dimaksud menjadi batal demi hukum serta tidak memiliki kekuatan mengikat.

\section{Resolusi 1497 Mencabut Judicial Jurisdiction Negara Lain}

Sebagaimana telah disinggung sebelumnya, beberapa keberatan yang diajukan terhadap paragraph 7 Resolusi 1497 antara lain adalah ketentuan paragraph 7 hanya mencakup personil dari negara penyumbang pasukan yang berasal dari negara non pihak dalam Statuta Roma 1998. Dengan demikian akan menciptakan perbedaan perlakuan antara anggota pasukan yang berasal dari negara pihak dan non pihak Statuta Roma 1998.

${ }^{27}$ I Wayan Parthiana, 2005, Hukum Perjanjian Internasional Bagian 2, Mandar Maju, Bandung, hlm. 304

${ }^{28}$ Ibid 
Keberatan berikutnya adalah adanya pengakuan pemberian yurisdiki eksklusif pada negara pengirim terhadap semua pelanggaran yang dilakukan anggota pasukan yang berasal dari negaranya. Hal ini berarti mengabaikan yurisdiksi territorial yang dimiliki negara tuan rumah tempat dilakukannya pelanggaran, yurisdiski negara-negara lain terkait dengan yurisdiksi universal dalam hukum internasional serta yurisdiksi nasional negara asal korban. Dapat diberikan contoh misalnya A, anggota pasukan perdamaian dari Amerika Serikat melakukan kejahatan internasional terhadap sesama anggota pasukan PBB dari Ghana. Dalam kasus ini hanya Amerika yang memiliki yurisdiksi terhadap A. Sebaliknya bila pelaku berasal dari negara pihak Statuta Roma maka negara teritorial, negara asal korban, negara asal pelaku, bahkan ICC dan semua negara lain memiliki judicial jurisdiction apabila jenis kejahatannya masuk kategori international crime yang memiliki universal jurisdiction. Dengan demikian ketentuan paragraph 7 tidak hanya menghambat ICC untuk melaksanakan yurisdiksinya tetapi juga mencabut hak semua negara yang memiliki yurisdiksi pidana terhadap kasus tersebut.Tidak berlebihan kiranya apabila dikatakan bahwa ketentuan dalam paragraph 7 yang menimbulkan diskriminasi antara sesama anggota pasukan PBB telah melanggar prinsip equality between individuals.

Beberapa pakar hukum internasional mengemukakan bahwa apa yang dimuat Paragraf 7 sebenarnya bukanlah hal baru karena PBB biasanya membuat perjanjian dengan host state ketika mengirimkan pasukan ke negara tersebut. Perjanjian ini pada umumnya diwadahi dalam apa yang dikenal sebagai Status of Forces Agreements (SOFAs). Latar belakang dibuatnya SOFAs adalah untuk memberikan ketenangan pada anggota pasukan perdamaian dalam melaksanakan tugas resminya. Seringkali sistem hukum dari negara di mana ia ditugaskan sangat buruk, tidak menjamin dan melaksanakan hak-hak para tersangka atau terdakwa maka mereka akan lebih merasa nyaman jika diadili di depan pengadilan nasional mereka sendiri. Namun demikian prosedur standar dalam SOFAs bukanlah memberikan yurisdiksi eksklusif pada negara pengirim melainkan memberikan primary jurisdiction pada sending state. Negara pengirim memang memiliki hak utama untuk memutuskan akan melaksanakan yurisdiksinya atau tidak. Negara ini harus memberitahukan pada negara-negara terkait secepat mungkin. Apabila negara pengirim diindikasikan unwilling atau unable maka masih terbuka bagi negara lain termasuk pengadilan internasional untuk melaksanakan yurisdiksinya. 
Hal kedua yang tidak sesuai dengan prosedur SOFAs adalah bahwa di dalam SOFAs hanya mencakup jenis tindakan tertentu. Adapun dalam resolusi 1497 mencakup segala jenis tindakan, nampak dari statement ...for all alleged acts or omissions arising out of or related to the Multinational Force or United Nations stabilizations force...

Haruslah ada pembatasan yang jelas sebenarnya hubungan antara tindakan seorang anggota pasukan PBB di bawah mandat PBB dengan tindakan atau kelalaian yang diluar mandat resminya. Sebagai contoh dapat dikemukakan misalnya tindakan seorang anggota pasukan PBB yang membunuh penduduk sipil dalam operasi militer yang dilaksanakan untuk menjamin dapat terlaksananya bantuan kemanusiaan PBB. Tidak diragukan lagi negara asal si anggota pasukan itu memiliki yurisdiksi utama mengadili yang bersangkutan. Namun tindakan seorang anggota pasukan yang memperkosa, memaksa penduduk sipil melakukan prostitusi, melakukan perdagangan manusia atau tindakan-tindakan sejenis lainnya tentulah tidak masuk kategori dalam ruang lingkup mandat resmi PBB. Manakala itu tidak masuk dalam kapasitas atau mandat resminya maka negara yang dirugikan seperti negara di mana kejahatan itu dilakukan dapat melaksanakan yurisdiksinya.

\section{Resolusi 1497 Tidak Sesuai dengan Hukum Perjanjian Internasional}

Sebagaimana diketahui paragraph 7 Resolusi 1497 berisikan ketentuan yang mengeliminasi yurisdiksi ICC terhadap kejahatan yang dilakukan oleh anggota pasukan PBB yang berasal dari negara non anggota Statuta Roma 1998. Statuta Roma 1998 adalah perjanjian internasional yang ditandatangani oleh lebih dari 100 negara. Sebagai perjanjian internasional maka prinsip-prinsip hukum perjanjian internasional berlaku padanya.

Pasal 39, 40,dan 41 Konvensi Wina 1969 tentang perjanjian internasional berisikan norma yang sudah menjadi hukum kebiasaan internasional. Pasal 39 Konvensi Wina menetapkan bahwa ...A treaty may be amended by agreement between the parties... .Selanjutnya Pasal 40 tentang amandemen untuk perjanjian multilateral juga menetapkan bahwa bila tidak ditentukan lain maka setiap usulan untuk mengamandemen harus diberitahukan pada semua pihak peserta perjanjian dengan prosedur-prosedur tertentu.

Pasal 41 menetapkan bahwa apabila tidak ditentukan lain maka dua atau lebih pihak pada perjanjian dapat menutup perjanjian untuk mengubah perjanjian di antara mereka jika: (a) kemungkinan perubahan demikian diperbolehkan oleh perjanjian itu, (b) penyesuaian itu sendiri 
tidak dilarang oleh perjanjian dan: (1) tidak mempengaruhi pihak-pihak lainnya menikmati hak-hak mereka atau pelaksanaan kewajiban di bawah perjanjian itu; (2) tidak mengaitkannya dengan suatu ketentuan, yang menyimpang atau tidak sesuai dengan objek dan tujuan perjanjian secara keseluruhan.

Selanjutnya, Pasal 121 dan 122 Statuta Roma 1998 yang mengatur masalah amandemen menetapkan bahwa amandemen dapat dilakukan oleh setiap negara peserta Statuta Roma setelah 7 tahun sejak Statuta Roma berlaku yang berarti baru pada tahun 2009 Statuta ini dapat diamandemen. Usulan amandemen harus diserahkan pada Sekjend PBB untuk diberitahukan pada negara-negara peserta yang lain. Usulan amandemen akan dibahas pada sidang yang diikuti oleh semua negara peserta Statuta Roma.

Dari ketentuan di atas nampak bahwa menurut hukum perjanjian internasional, sepanjang tidak ditentukan lain perjanjian hanya dapat diubah oleh para pihak dalam perjanjian tersebut. Selanjutnya Statuta Roma sendiri menetapkan bahwa Statuta hanya dapat diubah paling cepat tahun 2009 dan harus melalui usulan yang diajukan oleh negara peserta Statuta.

Dalam kaitannya dengan Resolusi 1497 dapat dikemukakan bahwa Dewan Keamanan meskipun merupakan organ tetap PBB tetapi lembaga ini bukanlah peserta Statuta Roma 1998. Dengan demikian Dewan Keamanan tidak berhak untuk mengubah isi ketentuan Pasal 16 Statuta Roma 1998 yang mengeliminasi yurisdikisi ICC terhadap anggota pasukan PBB yang berasal dari non state party Statuta Roma 1998. Tidak ada pula ketentuan dalam Piagam PBB yang memberi kewenangan pada Dewan keamanan untuk bertindak dengan cara mengubah suatu perjanjian internasional yang lain. ${ }^{29}$ Dapat disimpulkan oleh karenanya bahwa Dewan Keamanan telah bertindak melampau batas kewenangannya.

Pembelaan yang dikemukakan pakar-pakar hukum internasional yang mendukung Amerika Serikat menyatakan bahwa Resolusi 1497 dikeluarkan tidak berdasarkan Pasal 16 Statuta Roma. Di samping itu Resolusi pun tidak mengurangi para pihak-pihak dalam Statuta Roma untuk menikmati hak-haknya, Resolusi juga tidak bertentangan dengan objek dan tujuan Statuta menurut mereka. Hal ini menurut mereka karena adanya prinsip komplementer yang dianut Statuta Roma. Resolusi yang

\section{${ }^{29} \mathrm{Ibid}$}


memberikan exclusive jurisdiction pada sending state tidaklah bertentangan dengan prinsip komplementer. Statuta roma bertujuan agar seseorang yang melakukan kejahatan internasional yurisdiksi ICC tidak lepas dari sanksi. Dengan memberikan exlusive jurisdiction tidak berarti bahwa pelaku akan bebas dari penghukuman dengan demikian tidak bertentangan dengan objek dan tujuan Statuta juga dengan keberadaan ICC yang merupakan pengadilan pelengkap/kompelemnter dari pengadilan nasional. Resolusi 1497 menurut mereka tetap memberi peluang pada ICC untuk melaksanakan yurisdiksinya bilamana sending state melepaskan haknya untuk mengadili pelaku.Argumen ini dengan mudah dapat dibantah karena Resolusi 1497 jelas-jelas telah mengurangi hak negara peserta Statuta Roma khususnya negara di mana kejahatan berlangsung untuk melaksanakan judicial jurisdiction-nya karena dengan memberikan exclusive jurisdiction berarti hanya sending state yang memiliki yurisdiksi. Apabila sending state unwilling atau unable untuk mengadili pelaku dan tidak melepas haknya maka sangat besar kemungkinan pelaku akan bebas dari penghukuman. Prinsip pengadilan komplementer dalam Statuta Roma dilaksanakan sepanjang pengadilan nasional mau dan mampu untuk melaksanakan yurisdiksinya tanpa mensyaratkan adanya pelepasan hak lebih dulu dari sending State. Dengan demikian, dapat disimpulkan di samping tidak sesuai dengan prosedur dalam hukum perjanjian internaisonal tentang amandemen dan modifikasi perjanjian internasional, substansi Resolusi 1497 bertentangan dengan Statuta Roma 1998.

Berdasarkan prinsip Pacta Sunt Servanda pihak dalam perjanjian harus melaksanakan perjanjian dengan iktikad baik. Prinsip Pacta Sunt Servanda merupakan norma fundamental yang mempunyai kedudukan sebagai jus cogens dalam hukum internasional. Setiap Resolusi yang isinya memaksa pihak-pihak dalam suatu perjanjian untuk bertindak tidak konsisten dengan perjanjian tersebut merupakan pelanggaran terhadap prinsip Pacta Sunt Servanda. ${ }^{30}$ Piagam PBB sendiri menyatakan komitmennya untuk menghormati kewajiban-kewajiban yang muncul dari suatu perjanjian internasional. Preambule Piagam yang merupakan bagian tak terpisahkan dari Piagam PBB serta travaux preparatories dari Piagam PBB menunjukkan keinginan para pembentuk PBB untuk menghormati perjanjian-perjanjian internaisonal yang ada sebagai syarat penting untuk mewujudkan ketertiban dan stabilitas internasional. Oleh karena itu,

${ }^{30}$ Neha Jain, Op.Cit., hlm. 8 
keberadaan suatu resolusi yang menimbulkan akibat perubahan perjanjian internasional seperti Statuta Roma merupakan pelanggaran terhadap hukum internasional.

Salah satu pasal yang sering digunakan Dewan Keamanan juga Amerika Serikat untuk menjustifikasi Resolusi 1497 adalah keberadaan Pasal 103 Piagam PBB. Pasal 103 Piagam PBB menetapkan bahwa In the event of a conflict between the obligations of the members of the United Nations under the present Charter and their obligations under any other international agreement, their obligation under the present Charter shall prevail. Latar belakang dikeluarkannya Pasal 103 adalah mengingat ketentuan-ketentuan yang ada dalam piagam PBB sebagian besar merupakan prinsip-prinsip fundamental hukum internasional yang memiliki kedudukan sebagai peremptory norms atau jus cogens serta prinsip-prinsip hukum umum (the general principles of law). Sifat mengikat Piagam jauh lebih kuat dan imperatif dibandingkan dengan suatu perjanjian internasional yang tidak tergolong jus cogens ataupun yang merupakan hasil kesepakatan antara para pihak yang lebih bersifat kontraktual. Dengan demikian sangat wajar kiranya jika ada perjanjian internasional yang bertentangan dengan Piagam maka Piagamlah yang diutamakan. Sifat mengikat Piagam jauh lebih kuat dan imperatif dibandingkan dengan suatu perjanjian internasional yang tidak tergolong jus cogens ataupun yang merupakan hasil kesepakatan antara para pihak yang lebih bersifat kontraktual. ${ }^{31}$ Di samping itu, hal ini dimaksudkan untuk mencegah suatu negara membuat perjanjian yang bertentangan dengan jus cogens. ${ }^{32}$

Sepintas pasal ini bisa ditafsirkan menempatkan Resolusi 1497 lebih tinggi kedudukannya daripada Statuta Roma karena Resolusi adalah produk dari organ utama PBB yang mengikat pada seluruh anggota PBB sehingga bisa mengalahkan semua perjanjian internasional yang lain termasuk Statuta Roma 1998. Namun demikian perlu selain harus memahami maksud pembentuk PBB mencantumkan Pasal 103 Piagam sebagaimana telah dikemukakan dalam paragraf sebelumnya harus diingat pula bahwa Resolusi Dewan Keamanan bukanlah perjanjian internasional tetapi lebih tepat dikategorikan sebagai legislative act atau lebih tepatnya lagi sebagai executive act. ${ }^{33}$ Terlebih lagi, Resolusi 1497 merupakan penyalahgunaan kewenangan yang dilakukan oleh Dewan

\footnotetext{
${ }^{31}$ I Wayan Parthiana, Op.Cit., hlm 302-303

${ }^{32}$ Neha Jain, Op.Cit., hlm.10

${ }^{33} \mathrm{Ibid}$
} 
Keamanan. Dengan demikian kurang tepat untuk menggunakan Pasal 103 dalam membahas hubungan antara Resolsui Dewan Keamanan dengan Statuta Roma.

\section{Akibat Hukum Resolusi 1497}

Hukum internasional tidak memberikan jawaban yang jelas berkaitan dengan konsekuensi dari suatu tindakan yang tidak sah (illegal) yang dilakukan oleh suatu organisasi internasional, atau organ dari organisasi internasional tersebut. Dalam praktek irregular act yang dilakukan oleh suatu organisasi internasional mungkin valid, null atau voidable. Meskipun demikian tidak berarti tindakan yang dilakukan oleh suatu organisasi internasional tidak dapat dianalisis. Dengan segala keterbatasan yang ada Resolusi 1497 ini akan diuji dari sudut pandang Piagam PBB sebagai aturan tertinggi dalam PBB serta dari sudut pandang Statuta Roma sendiri sendiri sebagai perjanjian internasional yang terkena dampak langsung Resolsui 1497 tersebut.

\section{Akibat Hukum Resolusi 1497 terhadap Anggota PBB}

Kewenangan Dewan Kemanan diperoleh atas dasar pendelegasian kewenangan seluruh anggota PBB. Dalam pendelegasian wewenang ini terdapat pembatasan-pembatasan yang mengikat Dewan Keamanan. Dapat dikemukakan misalnya bahwa di satu sisi ada hak untuk membela diri (right of self defence) yang diatur dalam Pasal 51 Piagam. Di sisi lain, hak ini dibatasi oleh sistem keamanan bersama (colective security) yang merupakan satu-satunya perkecualian misalnya aturan tentang larangan .penggunaan kekerasan yang tercantum dalam Pasal 2(4). Oleh karenanya otorisasi Resolusi dalam konteks keamanan bersama harus didasarkan atas norma fundamental yang tercantum dalam Pasal 2(4). Terkait dengan Pasal 2(4) juga adalah ketentuan larangan agresi yang merupakan jus cogens atau peremptory norms. Keberadaan Peremptory norms adalah untuk melindungi nilai-nilai dan kepentingan yang amat fundamental bagi masyarakat internasional keseluruhan. Sudah menjadi pemahaman umum dalam hukum internasional bahwa negara tidak dapat membuat suatu perjanjian internasional yang bertentangan dengan prinsip jus cogens atau peremptory norms. Dengan demikian ketika negara mendirikan suatu organisasi internasional, negara tidak dapat mendelegasikan kewenangannya 
lebih dari yang mereka sendiri dapat lakukan (nemo plus juris transfer quam ipse habet). Dalam kasus Dewan Keamanan, organ inipun harus bertindak sesuai dengan ketentuan piagam, dan kewenangannya harus dilaksanakan sesuai dengn peremptory norms. Akhirnya dapat disimpulkan bahwa Resolusi Dewan Keamanan bukan hanya merupakan bagian dari secondary law, tunduk pada Piagam melainkan juga bagian dari suatu sistem yang secara keseluruhan merupakan subordinat dari jus cogens. ${ }^{34}$

Di samping larangan penggunaan kekerasan Pasal 2(4), prinsip self determination dan fundamental human right, juga prinsip pacta sunt servanda adalah bagian dari tujuan dan prinsip-prinsip organisasi sesuai dengan pembukaan dan Pasal 1 Piagam yang juga merupakan jus cogens.

Dalam kaitannya dengan Resolusi 1497 pertanyaan yang muncul adalah bagaimana akibat hukum Resolusi 1497 terhadap anggota PBB. Mayoritas anggota PBB saat ini juga merupakan negara pihak dalam Statuta Roma mengingat lebih dari 100 negara telah meratifikasi Statuta Roma 1998. Ketika ada konflik antara Resolusi 1497 dengan Statuta Roma 1998 ketentuan mana yang harus diutamakan oleh anggota PBB yang sekaligus juga negara pihak dalam Statuta Roma 1998?

Sebagaimana telah diuraikan dalam sub-sub bab sebelumnya, Resolusi Dewan Keamanan meskipun hanya diputus oleh 15 negara anggotanya mengikat pada semua anggota PBB berdasarkan Pasal 25 Piagam PBB karena negara anggota PBB telah memberi kewenangan pada Dewan Keamanan untuk bertindak atas nama mereka. Namun demikian harus diingat bahwa Resolusi tersebut harus sesuai dengan Piagam PBB. Manakala Resolusi tersebut tidak sesuai dengan Piagam sebagaimana telah diuraikan dalam sub bab sebelumnya seperti tidak ada terpenuhinya syarat yang disyaratkan BAB VII Piagam, tidak adanya hubungan antara ancaman perdamaian keamanan internasional dengan perlunya memberikan exclusive jurisdiction pada anggota pasukan PBB yang berasal dari non state party yurisdiksi ICC, pelanggaran terhadap prinsip persamaan kedudukan negara, prinsip pacta sunt servanda juga pelanggaran terhadap prinsip tidak merugikan negara lain, maka Resolusi tersebut tidak menimbulkan akibat hukum pada seluruh anggota PBB khusunya negara pihak Statuta Roma. Negara pihak dalam Statuta Roma yang diwilayahnya terjadi

${ }^{34}$ Efthymios Papastavridis, 2007, “Interpretation of Security Council Resolution Under Chapter VII in The Aftermath of the Iragi Crisis", dalam International \& Comparative Law Quarterly, 56 ICLQ 83, January 2007, hlm. 17-18 
kejahatan internaisonal yang menjadi ruang lingkup yurisdiksi ICC tetap dapat melaksanakan judicial jurisdictionnya maupun menyerahkan pelaku kepada ICC.

\section{Akibat Hukum Resolusi 1497 terhadap ICC}

ICC adalah subjek hukum tersendiri yang terbentuk melaui Statuta Roma 1998. lembaga ini merupakan lembaga independen, badan hukum tersendiri, tidak masuk dalam struktur organisasi PBB. Sebagai subjek hukum internasional ICC memiliki internasional personality dan international legal capacity. Hal ini nampak dari ketentuan-ketentuan yang dalam instrumen dasarnya seperti bahwa ICC menikmati privileges dan inviolability di negara anggotanya juga, ICC dapat membuat perjanjian internasional dengan subyek hukum internasional lain. Kedudukan ICC tidaklah berada di bawah Dewan Keamanan atau organisasi internasional yang lain. Meskipun demikian tidak berarti bahwa ICC memiliki kedudukan lebih tinggi dari yang lain. Baik ICC maupun Dewan Keamanan memiliki tugas dan kewenangan sendiri-sendiri. Dapat dikemukakan, misalnya bahwa ICC tidak berwenang mengubah Piagam PBB atau membatasi kewenangan Dewan Keamanan dalam melaksanakan tugas utamanya memelihara perdamaian keamanan internasional. Demikian pula sebaliknya Dewan Keamanan juga tidak berwenang mengubah Statuta Roma termasuk mengeliminasi yurisdiksi ICC .

Di sisi lain Pasal 25 Piagam PBB yang menjadi dasar Dewan Keamanan untuk memaksa anggota PBB mematuhi resolusi tersebut tidaklah dapat ditujukan pada ICC. Hal ini karena Pasal 25 Piagam PBB hanyalah ditujukan pada negara bukan institusi seperti halnya ICC. Dengan demikian Resolusi 1497 hanya menciptakan kewajiban hukum yang mengikat bagi negara dan tidak menimbulkan akibat hukum pada ICC. ICC tetap dapat melaksanakan yurisdiksinya ketika negara dimana kejahatan internasional berlangsung menyerahkan pelaku yang berasal dari non state party pada ICC.

\section{Penutup}

Berdasarkan uraian di atas dapat disimpulkan bahwa, Resolusi 1497 Dewan Keamanan tidak sesuai dengan hukum internasional. Ketidaksesuaian yang dimaksud adalah sebagai berikut: (a) Resolusi 1497 
khususnya paragraf 7 tidak sesuai dengan Piagam PBB. Tidak ada pertautan antara pertimbangan adanya ancama perdamaian keamanan internasional dengan perlunya mengeliminasi yurisdiksi ICC terhadap anggota pasukan PBB yang berasal dari negara non anggota Stauta Roma 1998 sebagaimana disyaratkan dalam BAB VII Piagam. Paragraf 7 Resolusi melanggar prinsip equity before the law antar sesama anggota pasukan $\mathrm{PBB}$, melanggar prinsip persamaan kedaulatan negara anggota PBB serta merugikan kepentingan banyak negara; (b) Resolusi 1497 khususnya paragraph 7 tidak sesuai dengan prinsip-prinsip yurisdiksi negara dalam hukum internasional. Paragraf 7 telah mencabut judicial jurisdiction negara dimana kejahatan berlangsung, negara asal korban, ICC, juga semua negara yang ada bilamana kejahatan yang terjadi masuk kategori kejahatan internasional yang terhadapnya berlaku yurisdiksi universal; (c) Resolusi 1497 khususnya paragraf 7 tidak sesuai dengan prinsip-prinsip dalam hukum perjanjian internasional. Dewan Keamanan tidak berhak melakukan amandemen atau memodifikasi Pasal 16 Statuta Roma 1998, karena hanya negara pihak dalam Statuta Roma yang berhak melakukan amandemen. Amandemen hanya bisa dilakukan 7 tahun terhitung sejak Statuta berlaku yaitu tahun 2009 kelak dan harus melalui prosedur-prosedur yang telah ditetapkan baik oleh Konvensi Wina 1969 tentang perjanjian internasional maupun oleh Statuta Roma 1998.

Akibat hukum Resolusi 1497 ICC dan PBB, dalam hal ini adalah Dewan Keamanan, merupakan dua subjek hukum internasional yang independen, memiliki tugas, dan kewenangan yang berbeda satu sama lain, serta tidak ada satu yang lebih tinggi dari yang lain. Dengan demikian ketentuan Resolusi khususnya paragraph 7 tidak menimbulkan akibat hukum pada ICC serta negara peserta Statuta Roma 1998. ICC tetap dapat melaksanakan yurisdiksinya terhadap anggota pasukan PBB yang berasal dari negara non anggota Statuta Roma 1998 bilaman negara tempat terjadinya kejahatan yang merupakan negara anggota Statuta Roma menyerahkan pelaku pada ICC. Adapun terhadap anggota PBB sendiri, meskipun pasal 103 Piagam memberi kedudukan lebih tinggi pada Piagam dibandingkan dengan perjanjian-perjanjian internasional yang lain namun demikian mengingat Resolusi bukanlah perjanjian internasional, juga resolusi 1497 itu sendiri mengandung ketentuan yang bertentangan dengan Piagam maka Pasal 103 piagam tidak dapat diterapkan dalam kasus konflik antara Resolusi 1497 dengan Statuta Roma 1998. Resolusi 1497 tidak mengikat negara anggota PBB. 


\section{Daftar Pustaka}

Babback Sabahi," The ICJ's Authority to invalidate The Security Council's Decisions Under Chapter VII: Legal Romanticism or The Rule of Law?, "dalam New York International law Review, summer 2004

Dinah Shelton, "Normative Hierarchi in International Law" , dalam American Journal of International Law (AJIL) , 100 Am.J.Int'1 L.291, April, 2006

Dixon, Martin, Textbook on International Law, fourt edition, Blackctone Press Limited, London, United Kingdom, 2000

Efthymios Papastavridis ,2007, "Interpretation of Security Council Resolutions under Chapter VII in the aftermath of the Iraqi Crisis," dalam International E Comparative Law Quarterly, 56 ICLQ 83, January 2007,

I Wayan Parthiana, 2005, Hukum Perjanjian Internasional Bagian 2, Mandar Maju, Bandung,

Louis B Sohn, "The Security Council's Role in the Settlement of International Disputes", Editorial Comment by the American Society of International Law, 78 American Journal of International law 402, April, 1984

Madeline Morris, "High Crimes and Misconceptions: The ICC and Non-Party States" dalam . Law \& Contemporary Problems, 2001

Morten Bergsmo et al., "Deferral of Investigation or Prosecution, in Commentary on the Rome Statute", 64 Law \& Contemp. Probs. 1, 2000

Mochtar Kusumaatmadja, Pengantar Hukum Internasional, Buku I Bagian Umum, Binacpta, Jakarta, catakan keempat, 1982

Mohamed El Zeidy, 2002, "The United States Dropped The Atomic Bomb of Article 16 of the ICC Statute :Security Council power of Deferrals and Resolution 1422", dalam Vanderbilt Journal of Transnational Law, November, 2002

Neha Jain, "A Separate Law for Peacekeepers : The Clash Between The Security Council and The International Criminal Court", dalam European Journal of International Law, April, 2005

Salvatore Zappala," Are Some Peacekeepers Better Than Others? UN Security Council Resolution 1497 (2003) and the ICC", dalam Journal of International Criminal Justice , 671, December, 2003,

\section{Dokumen:}

S/RES/1422 (2002), Adopted by the Security Council at its 4572nd meeting, on 12 July 2002

S/RES/1487 (2003), Adopted by the Security Council at its 4772 nd meeting,on 12 June 2003 
S/RES/1497 (2003), Adopted by the Security Council at its 4803rd meeting, on 1 August 2003

Vienna Convention 1969 on the Law of Treaties

Vienna Convention on the Law of Treaties between States and International Organizations or between International Organizations

United Nations Charter

Rome Statute 1998 regarding the International Criminal Court. 